\title{
Establishment of Evaluation Index System of Nature Reserve Vegetation_-A Case Study of Reed in the Core Region of Tianjin Qilihai Wetland
}

\author{
C.L. Chu, K. Wu, X.X. Ruan, G.Z. Wang, Y.R. Li, J. Li \& D.D. Wang \\ College of Environmental science and engineering, NanKai University, China
}

\begin{abstract}
KEYWORD: DPSIR model; Reed; Index system; Qilihai wetland
ABSTRACT: Vegetation is the core protection object in nature reserve and establishing index sytem of the growth status of vegetation and analyzing the influencing factors are the basis of vegetation protection in nature reserve. Based on DPSIR model and the principles of science, comprehensiveness, difference, early warning and guidance, the selection of index from perspectives of driving forces, pressure,state,impact and response is put forward. The establishment of index system of the growth of reed for the core region in Qilihai wetland provide methods for evaluation of the growth and influencing factors of reed, and service to the reed restoration for the core region in Qilihai wetland.
\end{abstract}

\section{BACKGROUND}

It is a marine and coastal ecosystem type Nature Reserve of natural level approved by the State Council. The Nature Reserve is located in the north temperate summer monsoon climate zone by the side of Bohai Gulf. The wild plants are distributed unevenly in the Nature Reserve. The protection of wetland natural environment and its ecological system is a priority in the Nature Reserve, while the vegetation system is the basis of the whole ecological system, thus scientific and effective protection of the wild plants is necessary. Qilihai Wetland, located in the west south part of Ninghe County of Tianjin, is an important part of the Nature Reserve and also a very special area for its richness in the species diversity of Tianjin. The Wetland is divided into core region and experiment region. Qilihai Wetland plays an important role in regulating flows, storing flood-water for use in a drought, preserving the species diversity and developing recreation and tourism. In Qilihai Wetland, the reed flourishes. Reed enjoys a higher economic, ecological and social value, however, the growth of reed is influenced by some factors, for example, harvesting the reed for pulp, high density cultivation, the abuse of pesticide, changing wetland to dry land, the construction of road, the unstable raindrops, the insufficient replenishment of water and other natural factors. As a result, the ecological function of Qilihai Wetland could not be exerted effectively. Thus, it is urgent to study the influence mechanism of reed growth and restore the wetland vegetation. To realize that, Tianjin Ocean Bureau launched the restoration and protection work in Qilihai Wetland in April, 2012 and made Planning for Protection and Restoration of Qilihai Wetlands in Tianjin Ancient Coastal and Wetland National Nature Reserve (2012-2015).

Our country issued a series of standards to evaluate the health of ecological environment, such as Standard for Sector-integrate Eco-industrial Parks, Technical Criterion for Ecosystem Status Evaluation and so on. Many scholars explored various factors influencing the reed growth, for example alternate dry and wet frequency ${ }^{[1]}$, deep groundwater ${ }^{[2]}$, water level and soil ${ }^{[3]}$, different management methods ${ }^{[4]}$ and so on. Responding mechanism to influence factors to reed growth is studied, and understanding of the reed growth mechanism is strengthened, which is significant to reed protection and usage.

Evaluation principles and methods to reed growth in Qilihai Wetland Core Area has been discussed on the basis of the analysis of the influencing factors to reed growth. DPSIR model is adopted, all kinds of index are put forward, and the evaluation index system is establish, which provides reference for the vegetation restoration in Qilihai and has significance in realistic guidance. 


\section{REED GROWTH IN THE CORE REGION OF QILIHAI WETLAND}

According to Planning for Protection and Restoration of Qilihai Wetlands in Tianjin Ancient Coastal and Wetland National Nature Reserve (2012-2015), vegetation restoration will be conducted in Qilihai Wetland with an area of 5,000 mu as the major experiment area, local wetland plants will be appropriately introduced to the west and east areas of Qilihai Wetland, restoration of water plants of submerged and emergent kinds will be conducted, diversity of the wetland vegetation will be restored and the natural characteristics with reed as the major vegetation in the wetland will be restored.

Qilihai is rich in the diversity of plants and vegetation resources with herbaceous plants being predominant, such as Reed green bristle grass, Puccinellia distans and so on. Reed field flourishes and covers about $3,555 \mathrm{hm}^{2}$ with a production of $3 \times 10^{4} \mathrm{t}^{[5]}$. As the largest reed supply area, Qilihai provides raw materials for paper making, weaving and construction, which not only brings huge economic value, but also ecological value for it helps to conserve the water resources, provide inhabitants for birds and so on. For many years, the reed field has been shrinking dramatically, the reed growth has been restrained, which directly influence the ecological function of Qilihai Wetland. The reasons are as follows: first, the weak ecological awareness of the farmers leads to abuse of pesticide and unreasonable harvest of reed; secondly, certain areas of wetland are transformed into man-made pond to raise crab, fish and shrimp to gain economic benefits; thirdly, due to the insufficient storage capacity of the reservoir, the reed field shrinks dramatically in Qilihai Wetland Core Region and the reed growth is influenced greatly, so is the ecological function of the Qilihai Wetland.

\section{DETERMINE THE PRINCIPLES AND METHODS OF THE EVALUATION INDEX}

Standard for Sector-integrate Eco-industrial Parks, Technical Criterion for Ecosystem Status Evaluation and other standards released by our government have provided guidance for ecological evaluation in China, provided support for improving the ecological quality, and improved the management of ecological quality. Establishing the Index System considers both the theoretical theory and practical application, which is an important stage to study the impact mechanism on reed growth in Qilihai Wetland Core Area. It is an important part to turn the restoration theory into practice in Qilihai Wetland. A few evaluation index exist concerning the reed growth impact mechanism, thus DPSIR Model is used to classify, analyze, and select the most quantitative and sensitive index. The selection procedure is as follows:

scientific principle The selection of index is based on scientific principle, guided by scientific theory and facts to reflect the impact mechanism of reed growth.

comprehensive principle The index system is evaluated by DPSIR Model from the perspectives of resources, environment, economy and society, which covers a lot of fields. In this way, the selected index will follow the comprehensive principle and reflect the reed growth impact mechanism from all round aspects.

Difference principle The selected evaluation index should be different according to the different situation in the fields of resources, economy and population in different areas. Evaluation index should be selected scientifically according to the evaluation target, that is to say, evaluation index should be selected according to the specific growth environment and growth characteristics in Qilihai Wetland Core Region.

Warning Guiding Principle Warning Guiding Principle mechanism to protect environment is the final fruit of DPSIR Model, which could guide the future development of the system scientifically. Thus the evaluation index should be forward-looking, guiding, and sensitive enough to give reasonable feedback to the change of the State. 


\section{DPSIR MODEL}

DPSIR Model was put forward in 1993 by OECD and then adopted by EEA. This model mainly explores the relationship between environmental system and human activities. DPSIR Model is systematic, flexible, comprehensive and it covers environment, society, resource and economy, thus it not only shows the impact of social and economic development and resources consumption by human activities on the environment, but also shows the feedback to the society by human activities and environmental resources status ${ }^{[6]}$.

In DPSIR Model, driving forces refers to the changes of society, economy, mechanism and regulations and the general trend of social economic activities and industrial development in the large scale. Pressure refers to the direct reason causing the change of environmental system by human activities. State refers to the environmental status under the above pressure. Impact refers to the change of environmental function due to the change of environmental state, thus positive or negative impact will cast upon society-economy and human health. Response refers to the positive policies and solutions adopted during the promotion of sustainable development ${ }^{[7-8]}$.

\section{REED GROWTH EVALUATION INDEX SYSTEM CONSTRUCTED IN QILIHAI WETLAND CORE REGION ON THE BASIS OF DPSIR MODEL}

In the DPSIR Model of reed growth in Qilihai, driving forces refer to the potential factor that influence the reed growth, including human production and life activities, economic development trend, the change of natural environment. The representative index include the natural growth rate of population, the change ratio of the wetland area, the development interfering index, the local GDP, the Per capita disposable income of urban residents, the consumption index, alien species invasion index, the environmental restraint index and so on. Pressure refers to the direct factors that influence the reed growth, including both physical and chemical factors. the representative index include water level, the water quality compliance rate, temperature, sunshine, land stress index, and pollution load index. State refers to the growth status of the reed. Representative index include the number of biomass, stem height, branch diameter, leaf area, number of leaves per plant and so on. Impact refer to the impact of reed growth on resources, environment, economy and society, such as Biological abundance index, Hydrology and climate regulation function, purification function, inhabitation function, raw material production capacity, tourism value and research and culture value and so on. Response refers to the policies adjustment according to the change of reed growth in Qilihai, including scientific management, pollution control. Representative index include vegetation cover index, area suitability index, emission standard rate and centralized sewage treatment rate of urban sewage.

Based on DPSIR model, this paper explores the causal relationship of reed growth circumstances in Qilihai Wetland Core Area from the perspective of resources, environment, economy and society development, puts forwards scientific and quantitative evaluation index, evaluates the factors influencing the weed growth, which provides methods for scientific evaluation of reed growth and its influence factors in Qilihai. The evaluation system could serve better the protection of reed in the wetland, realize scientific management and pollution control, which can give precaution and guild the ecological restoration of the reed. In this way, the ecological restoration can be promoted in in the Core Region of Tianjin Qilihai Wetland. 
Table 1. influence factors for reed growing of core area of Qilihai wetland

\begin{tabular}{|c|c|c|}
\hline type & influence & factors \\
\hline \multirow{3}{*}{$\begin{array}{l}\text { Driving } \\
\text { forces }\end{array}$} & $\begin{array}{l}\text { Production } \\
\text { and life of } \\
\text { people }\end{array}$ & $\begin{array}{l}\text { Growth rate of popula- } \\
\text { tion, change of wetland } \\
\text { area, interference index } \\
\text { of development }\end{array}$ \\
\hline & $\begin{array}{c}\text { Economic } \\
\text { development }\end{array}$ & $\begin{array}{l}\text { Regional domestic prod- } \\
\text { ucts, Urban per capita } \\
\text { disposable income, index } \\
\text { of price and consump- } \\
\text { tion }\end{array}$ \\
\hline & $\begin{array}{l}\text { Natural envi- } \\
\text { ronment } \\
\text { change } \\
\end{array}$ & $\begin{array}{l}\text { Alien species invasion } \\
\text { index, Environmental re- } \\
\text { strictions index }\end{array}$ \\
\hline \multirow[t]{2}{*}{ pressure } & $\begin{array}{l}\text { Physical in- } \\
\text { fluence }\end{array}$ & $\begin{array}{l}\text { Temperature, illumina- } \\
\text { tion, mechanical stimula- } \\
\text { tion(The impact of the } \\
\text { hail to leaf, etc), water } \\
\text { level }\end{array}$ \\
\hline & $\begin{array}{l}\text { Chemical in- } \\
\text { fluence }\end{array}$ & $\begin{array}{l}\text { Ratio up to the standard } \\
\text { of water quality, Stress } \\
\text { index of land, Pollution } \\
\text { load index }\end{array}$ \\
\hline State & $\begin{array}{l}\text { State of } \\
\text { growth }\end{array}$ & $\begin{array}{l}\text { Biomass, leaf yield, } \\
\text { plant height, branch di- } \\
\text { ameter, leaf area }\end{array}$ \\
\hline \multirow{4}{*}{ impact } & Resource & $\begin{array}{l}\text { Biological abundance } \\
\text { index, Water density in- } \\
\text { dex }\end{array}$ \\
\hline & Environment & $\begin{array}{l}\text { utility rate of luminous } \\
\text { energy, carbon dioxide } \\
\text { fixation, water area }\end{array}$ \\
\hline & Economy & $\begin{array}{l}\text { Annual yield of reed, At- } \\
\text { tract tourists }\end{array}$ \\
\hline & Society & $\begin{array}{l}\text { Number of related re- } \\
\text { search projects }\end{array}$ \\
\hline \multirow[t]{2}{*}{ response } & $\begin{array}{c}\text { Scientific } \\
\text { management }\end{array}$ & $\begin{array}{l}\text { Vegetation index, Area } \\
\text { of suitable index, Envi- } \\
\text { ronmental protection in- } \\
\text { vestment as a share of } \\
\text { GDP }\end{array}$ \\
\hline & $\begin{array}{l}\text { Pollution } \\
\text { control }\end{array}$ & $\begin{array}{l}\text { Pollution emissions suc- } \\
\text { cess rate, Urban sewage } \\
\text { concentrated rate }\end{array}$ \\
\hline
\end{tabular}




\section{ACKNOWLEDGEMENT}

This study was supported by the project of National Natural Science Foundation of China (No. 41301624) and the Research funds of Tianjin education social science major projects (mechanism and ways of ecological reform of industry of Tianjin by green consumption).

\section{REFERENCE}

[1] X.Y., Li., X.T., Liu., et al.(2015). Effect of dry-wet alternation frequency on the growth and physiological characteristics of reed. ACTA PRATACULTURAE SINICA, 2015,(3):99-107.

[2] F.L., Su., X.Y., Zhang., et al.(2010). The Response Mechanism of Groundwater Depth and Reed Growth. Journal of Irrig ation and Drainage, 2010,06:129-132.

[3] J.Y., Ma.(2010). Effect of Water Level and Soil on Growth and Reproduction of Phragmites australis in Reclaimed Wetland of Chongming Dongtan. East China Normal University, 2010.

[4] Y.Q., Zhao., T.H., He., G.,J., Xia.(2014). Effects of different management approaches on Phragmites australis growth. Guangdong Agriculture Science, 2014,19:165-169.

[5] B.B., Hu., L.M., Xu., Z.J., Li, et al.(2012). Assessment on Qilihai Wetland Value in Tianjin City. Journal of Anhui Agri. Sci, 2012,40(21):11001-11004.

[6] C.F., Shao., M.T., Ju.(2010). Study of the Index System of Low-Carbon Cities Based on DPSIR Model. ECO

LOGICAL ECONOMY, 2010,10:95-99.

[7]J., W., G.B., Liu., G.H., Zhang., \& Q.K., Yang.(2013). Evaluating eco-environmental effects of "Grain for green" project based on DPSIR framework in the Loess hilly region. SHUILI XUEBAO, 2013,02:143-153.

[8] X., Zhu., Z.N., Lu.(2013). Evaluation on the Low-carbon City Development based on DPSIR Model-The Case of Jiangsu Province. Technoeconomics \& Management Research, 2013,01:115118. 